(2) Open Access Full Text Article

\title{
Association of GSTPI and PI 6 promoter methylation with the risk of HBV-related hepatocellular carcinoma: a meta-analysis
}

This article was published in the following Dove Press journal:

OncoTargets and Therapy

\author{
Qin $\mathrm{Li}^{\prime}$ \\ Cunliang Deng' \\ Ting Zhang' \\ Xiang $\mathrm{Li}^{2}$ \\ 'Department of Infectious Diseases, \\ The Affiliated Hospital of Southwest \\ Medical University, Luzhou, Sichuan \\ Province, People's Republic of China; \\ ${ }^{2}$ School of Pharmacy, The Southwest \\ Medical University, Luzhou, Sichuan \\ Province, People's Republic of China
}

Correspondence: Xiang Li School of Pharmacy, The Southwest Medical University, No 319 of Zhongshan Road 3, Luzhou, Sichuan Province 646000, People's Republic of China Tel +868303162075

Fax +868303162075

Email scisciscilII@I63.com
Background: Study on the relationship between glutathione-S-transferase Pi 1 (GSTP1) and $\mathrm{P} 16$ promoter region methylation and the risk of hepatitis B virus-related hepatocellular carcinoma (HBV-related HCC) has produced inconsistent results.

Objectives: To assess the correlation between GSTP1 and P16 promoter methylation frequency and HBV-related HCC susceptibility.

Methods: All relevant studies were identified by searching PubMed, Embase, Web of Science, and China National Knowledge Infrastructure literature databases before December, 2017. The OR and the corresponding 95\% CI were calculated to investigate the risk of GSTP1 and P16 promoter methylation rate and HBV-related HCC. Sensitivity analysis was performed and publication bias was estimated using the Begg's and Egger's test.

Results: Our meta-analysis identified the relationships of GSTP1 (six studies including 213 HBV-related HCC tumor tissues) and P16 (nine studies with 287 HBV-related HCC tumor tissue) promoter methylation with HCC risk. Compared with normal liver tissue and cirrhosis, the pooled ORs of GSTP1 promoter region methylation in HBV-related HCC cancer tissues were 6.05 (95\% CI $=1.20-30.52$ ) and 5.21 (95\% CI $=2.19-12.41)$, respectively. Compared with paracancerous tissue, normal liver tissue, cirrhosis, and chronic hepatitis B as controls, the pooled ORs of P16 promoter region methylation in HBV-related HCC cancer tissues were 7.18 (95\% CI $=2.31-22.33), 24.89$ (95\% CI $=3.38-183.03), 5.92$ (95\% CI $=1.78-19.68)$, and $12.12(95 \% \mathrm{CI}=0.75-196.50)$.

Conclusion: In summary, our meta-analysis found strong associations between GSTP1 and P16 gene promoter methylation and an increased HBV-related HCC susceptibility. Moreover, GSTP1 and P16 methylation in promoter region could obviously increase the risk of HBV-related $\mathrm{HCC}$ in patients with cirrhosis, indicating that these would be promising biomarkers for early clinical diagnosis of HBV-related HCC.

Keywords: hepatocellular carcinoma, Hepatitis B virus, GSTP1, P16, meta-analysis

\section{Introduction}

Hepatocellular carcinoma (HCC), one of the leading malignancies, is a major cause of cancer-related death worldwide. ${ }^{1}$ As is known to all, HCC is a consequential complication of cirrhosis. ${ }^{2}$ In addition, epidemiological studies have provided overwhelming evidence that hepatitis $\mathrm{B}$ virus (HBV) infection is the main risk factor associated with the occurrence of chronic hepatitis B (CHB), cirrhosis, and HCC. Globally, 257 million people are chronic HBV carriers, and nearly one-quarter of them will develop HCC. ${ }^{3-5}$ Therefore, the progression of $\mathrm{HCC}$ in persons persistently infected with $\mathrm{HBV}$ is of great significance. However, the mechanisms contributing to the HBV-related HCC have not been fully elucidated. 
DNA methylation, a common epigenetic alteration, plays an important role in the regulation of gene expressions and other life activities. Previous studies have shown that aberrant promoter hypermethylation of many tumor suppressor genes (TSGs), which will lead to transcriptional repression and loss of gene function, may play a major role in the progression of tumorigenesis. ${ }^{6-8}$ In recent years, several aberrant methylations of tumor-associated genes have been observed in HCC. ${ }^{9-11}$ In consideration of the significance of HBV in the occurrence of HCC, it is necessary to further study whether aberrant DNA methylation of specific genes exerts a potential role in early detection of HBV-related HCC.

The glutathione S-transferase pi 1 (GSTP1) gene is considered to be a major TSG located on chromosome 16p13, belonging to a family of phase II metabolic enzymes, and plays a critical role in the prevention of hepatocyte mutation. ${ }^{12}$ In addition, the $p 16^{I N K 4 A}$ gene is a cell cycle-related gene located on chromosome 9p21 and plays a key role in cell cycle regulation. ${ }^{13,14}$ Preliminary reports have reported that GSTP1 and P16 promoter hypermethylation leads to the downregulation of gene expressions and contributes to an increase in the incidence of HBV-related HCC. ${ }^{15}$ However, the relationship of GSTP1 and P16 promoter methylation with $\mathrm{HBV}$-related $\mathrm{HCC}$ risk and pathogenesis remains controversial. ${ }^{15-26}$ Therefore, we carried out the current meta-analysis to comprehensively assess the associations of GSTP1 and P16 promoter methylation with the risk of HBV-related HCC.

\section{Methods}

\section{Search strategy}

Relevant literature was retrieved from PubMed, Embase, Web of Science, and China National Knowledge Infrastructure databases with a combination of the following words: "Hepatitis B Virus" or "HBV" and "hepatocellular carcinoma" or "HCC" and "GSTP1" or "glutathione-S-transferase P1" or "P16" and "methylation". All relevant articles were published before December 2017, without language restrictions. Literature searches were conducted independently by two reviewers using a standardized approach (Qin Li and Cunliang Deng). The references from relevant primary articles were manually searched to identify potential studies. Any disagreement was adjudicated by a third investigator (Xiang Li) after referring to original articles.

\section{Inclusion criteria and exclusion criteria}

We used the following inclusion criteria for our research: 1) studies that have a case-control design; 2) studies in which patients diagnosed with $\mathrm{HBV}$-related $\mathrm{HCC}$, cirrhosis, and $\mathrm{CHB}$ were accurately diagnosed according to the diagnostic criteria; 3) studies in which patients with HBV infection were diagnosed using a HBV surface antigen (HBsAg) serological assay; 4) methods suitable for the methylation detection were confined to MethyLight array, pyrosequencing, and methylation-specific polymerase chain reaction (MSP); and 5) studies primarily evaluating the frequency of GSTP1 or P16 promoter methylation in HBV-related HCC tissues with control group. Studies were excluded if they met one of the following criteria: 1) overlapping data or review articles; 2) studies in which patients had other severe diseases, such as other malignancies, heart failure, or kidney failure; and 3) studies in which patients received a combination of other treatments.

\section{Data extraction}

We recorded the following information: first author, publication year, geographical location, ethnicity, detection method of methylation, and frequency of methylation. The case numbers of HBV-related HCC, cirrhosis, CHB, paracancerous tissue, and normal liver tissue were separately extracted from the overall population after fully understanding the paper.

\section{Statistical analysis}

Meta-analyses were performed using STATA 12.0 (Stata Corporation, College Station, TX, USA). The strength of the associations between GSTP1 and P16 promoter methylation and the risk of HBV-related HCC was expressed as the ORs and $95 \%$ CIs. The Z-test was applied to estimate the statistical significance of pooled ORs. Between-study heterogeneity was evaluated by the Cochrane $Q$-statistic and $I^{2}$ test. The random-effects model was chosen when heterogeneity existed among studies $\left(I^{2}>50 \%\right)$. Otherwise, a fixed-effects model was applied. Sensitivity analysis was carried out to investigate the influence of single study on the final results. Egger's test, Begg's test, and funnel plots were performed to examine the publication bias. The results were displayed as forest plots and identified to be statistically significant when $P<0.05$.

\section{Results}

\section{Characteristics of studies}

The process of literature search is summarized in Figure 1. The original search yielded a total of 111 articles related to the searched keywords. According to the inclusion criteria, a total of 429 HCC samples with HBV infection in 12 studies were included; additionally, 173 adjacent samples, 


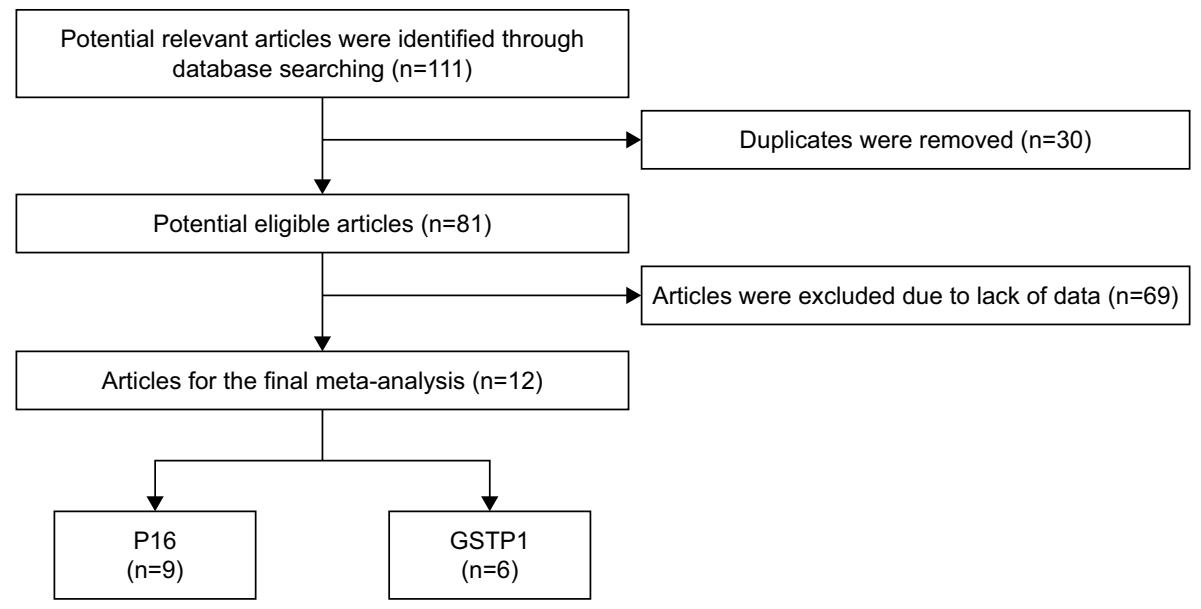

Figure I Flow diagram of search strategy and study selection for meta-analysis.

167 normal samples, 241 cirrhosis samples, and $190 \mathrm{CHB}$ samples were included. The publication year of the studies ranged from 2003 to 2017.

The geographic setting of the studies was heterogeneous: two studies were from Korea, eight were from China, one was from Japan, and one each from France and Thailand. The MSP method used for this meta-analysis was adopted in eight studies, one study was detected by pyrosequencing, and the other three studies were conducted using MethyLight array. The characteristics of the studies are summarized in Table 1.

\section{Association of GSTPI promoter region methylation with the risk of HBV-related $\mathrm{HCC}$}

Six studies were included to assess the potential role of GSTP1 promoter methylation in the risk of $\mathrm{HCC}$ in patients with HBV infection. A random-effects model was used where significant heterogeneity was found among the studies. Our findings demonstrated that the frequency of the GSTP1 gene methylation in neoplasm tissues was significantly higher than in the normal and cirrhosis tissues (neoplasm tissue vs normal tissue: $\mathrm{OR}=6.05,95 \% \mathrm{CI}=1.20-30.52$, $P<0.05$, Figure 2A and Table 2; neoplasm tissue vs cirrhosis tissue: $\mathrm{OR}=5.21,95 \% \mathrm{CI}=2.19-12.41, P<0.01$, Figure 2B and Table 2).

\section{Association of $\mathrm{PI} 6$ promoter region methylation with the risk of HBV-related HCC}

The pooled OR of P16 methylation in HBV-related HCC tissues was 7.18, with corresponding $95 \% \mathrm{CI}=2.31-22.33$, compared with adjacent tissues in the random-effects model $(P<0.01$; Figure $3 \mathrm{~A}$ and Table 2$)$. Compared with normal

Table I Clinicopathological features of eligible studies

\begin{tabular}{|c|c|c|c|c|c|c|c|c|c|c|c|c|c|c|c|}
\hline \multirow{2}{*}{$\begin{array}{l}\text { Gene } \\
\text { methylation }\end{array}$} & \multirow[t]{2}{*}{ References } & \multirow[t]{2}{*}{ Year } & \multirow[t]{2}{*}{ Country } & \multirow[t]{2}{*}{ Ethnicity } & \multirow[t]{2}{*}{ Method } & \multicolumn{2}{|c|}{ Neoplasm } & \multicolumn{2}{|c|}{ Adjacent } & \multicolumn{2}{|c|}{ Normal } & \multicolumn{2}{|c|}{ Cirrhosis } & \multicolumn{2}{|c|}{ CHB } \\
\hline & & & & & & $\bar{M}$ & $\mathbf{U}$ & $\bar{M}$ & $\bar{U}$ & $\bar{M}$ & $\bar{U}$ & $M$ & $\mathbf{U}$ & $\bar{M}$ & $\mathbf{U}$ \\
\hline \multirow[t]{7}{*}{$\overline{\text { GSTPI }}$} & Su et $\mathrm{al}^{15}$ & 2007 & China & Asian & MSP & 17 & 13 & 8 & 22 & - & - & - & - & - & - \\
\hline & Chang et $\mathrm{al}^{16}$ & 2008 & China & Asian & MSP & 10 & 3 & - & - & - & - & 6 & 11 & & \\
\hline & Feng et al ${ }^{17}$ & 2010 & China & Mixed & MethyLight & 8 & 4 & - & - & 13 & 12 & - & - & - & - \\
\hline & Lambert et al ${ }^{18}$ & 2011 & France and & Mixed & Pyrosequencing & 9 & 23 & - & - & 6 & 34 & 3 & 22 & - & - \\
\hline & & & Thailand & & & & & & & & & & & & \\
\hline & Qu et $\mathrm{al}^{19}$ & 2015 & China & Asian & MSP & 16 & 12 & - & - & 0 & 20 & - & - & - & - \\
\hline & Dong et $\mathrm{a}^{20}$ & 2017 & China & Asian & MethyLight & 17 & 81 & - & - & 0 & 80 & 2 & 73 & 0 & 90 \\
\hline \multirow[t]{9}{*}{ PI6 } & Shim et $\mathrm{a}^{21}$ & 2003 & Korea & Asian & MSP & 15 & 3 & - & - & - & - & 15 & 9 & - & - \\
\hline & Narimatsu et $\mathrm{a}^{22}$ & 2004 & Japan & Asian & MSP & 5 & 4 & - & - & - & - & 6 & 8 & 3 & 18 \\
\hline & Zhang et a $\left.\right|^{23}$ & 2006 & China & Asian & MSP & 29 & 3 & 4 & 28 & - & - & 15 & 26 & 3 & 51 \\
\hline & Su et $\mathrm{al}^{15}$ & 2007 & China & Asian & MSP & 14 & 16 & 5 & 25 & - & - & - & - & - & - \\
\hline & Zhu et $\mathrm{a}^{24}$ & 2007 & China & Asian & MSP & 11 & 12 & 4 & 19 & - & - & - & - & 9 & 16 \\
\hline & Chang et $\mathrm{al}^{16}$ & 2008 & China & Asian & MSP & 10 & 3 & - & - & - & - & 9 & 8 & - & - \\
\hline & Zhu et $\mathrm{al}^{25}$ & 2010 & China & Asian & MSP & 40 & 48 & 17 & 71 & - & - & - & - & - & - \\
\hline & Um et $a^{26}$ & 2011 & Korea & Asian & MethyLight & 22 & 24 & - & - & 0 & 2 & 0 & 45 & - & - \\
\hline & Qu et $\mathrm{al}^{19}$ & 2015 & China & Asian & MSP & 18 & 10 & - & - & 0 & 20 & - & - & - & - \\
\hline
\end{tabular}

Abbreviations: M, methylation; U, unmethylation; MSP, methylation-specific polymerase chain reaction; CHB, chronic hepatitis $B$. 

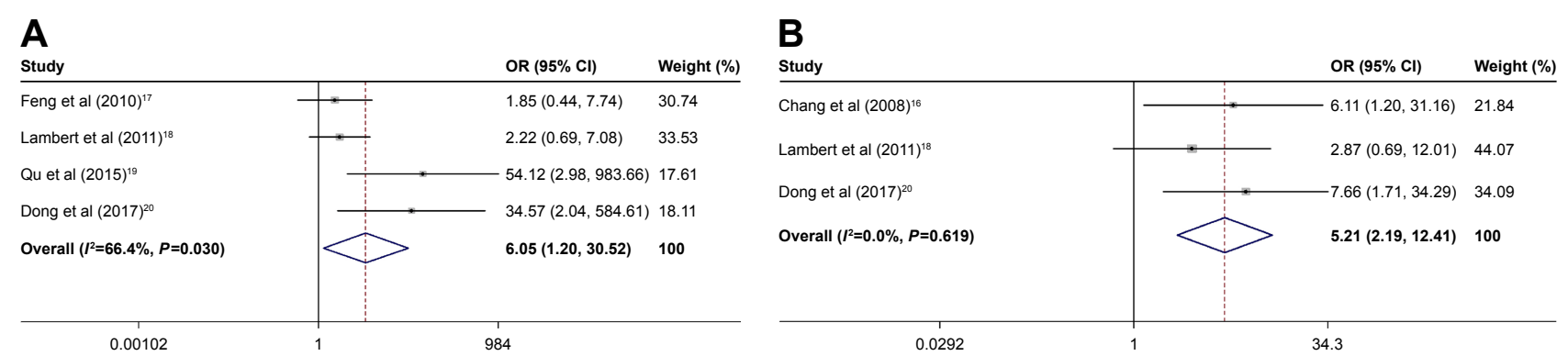

Figure 2 Forest plots of GSTPI promoter region methylation and the risk of HBV-related HCC.

Notes: (A) Neoplasm vs normal tissues; (B) neoplasm vs cirrhosis tissues. Each square represents an OR for each specific study, with square sizes proportional to the weight. Weights are from random-effects analysis.

Abbreviations: GSTPI, glutathione-S-transferase Pi I; HBV, hepatitis B virus; HCC, hepatocellular carcinoma.

tissues, the fixed-effects model was chosen to evaluate the association between the frequency of P16 methylation and the risk of HBV-related HCC, and a significant result was found $(\mathrm{OR}=24.89,95 \% \mathrm{CI}=3.38-183.03, P<0.01$; Figure $3 \mathrm{~B}$ and Table 2). Moreover, the pooled OR was 5.92 in HBV-related HCC tumor tissues vs cirrhosis tissues (95\% CI $=1.78-19.68, P<0.01$; Figure $3 \mathrm{C}$ and Table 2), indicating that $\mathrm{P} 16$ methylation in promoter region could obviously increase the risk of HBV-related HCC in patients with cirrhosis. However, no significant association was found between HBV-related HCC tumor tissues and CHB tissues $(\mathrm{OR}=12.12,95 \% \mathrm{CI}=0.75-196.50, P>0.05$; Figure 3D and Table 2).

\section{Sensitivity analysis}

Sensitivity analysis was performed to evaluate the effect of each study on overall meta-analysis by excluding one study at a time, but the pooled ORs were always constant, indicating that no individual study significantly affected the overall pooled estimates, and our results were robust.

\section{Publication bias}

Begg's and Egger's tests were used to investigate the publication bias. Begg's funnel plot showed no publication bias for the association between the methylation of GSTP1 and the risk of HBV-related HCC in cancerous and normal tissue, while the Egger's test indicated an opposite result. Moreover, results from our meta-analysis showed that there was no publication bias when assessing the GSTP1 methylation in HBV-related HCC tumor tissues vs cirrhosis tissues (Table 2 and Figure 4).

With regard to the association between the methylation of P16 and the risk of HBV-related HCC, the funnel plots presented no apparent asymmetry, and the Egger's tests

Table 2 Meta-analysis of the associations of GSTPI and PI6 gene methylation with HBV-related HCC pathogenesis

\begin{tabular}{|c|c|c|c|c|c|c|c|c|}
\hline \multirow[t]{2}{*}{ Clinical features } & \multirow[t]{2}{*}{$\begin{array}{l}\text { Studies } \\
\text { (n) }\end{array}$} & \multirow[t]{2}{*}{ Model } & \multirow[t]{2}{*}{ OR $(95 \% \mathrm{Cl})$} & \multirow[t]{2}{*}{$P$-value } & \multicolumn{2}{|c|}{$\begin{array}{l}\text { Heterogeneity } \\
\text { test }\end{array}$} & \multicolumn{2}{|c|}{ Publication bias } \\
\hline & & & & & $I^{2}(\%)$ & $P$-value & $\begin{array}{l}\text { Begg's } \\
\text { test }(P)\end{array}$ & $\begin{array}{l}\text { Egger's } \\
\text { test }(P)\end{array}$ \\
\hline $\begin{array}{l}\text { GSTPI methylation } \\
\text { (neoplasm vs normal) }\end{array}$ & 4 & $\begin{array}{l}\text { Random-effects } \\
\text { model }\end{array}$ & $6.05(1.20-30.52)$ & 0.03 & 66.4 & 0.03 & 0.09 & 0.04 \\
\hline $\begin{array}{l}\text { GSTPI methylation } \\
\text { (neoplasm vs cirrhosis) }\end{array}$ & 3 & $\begin{array}{l}\text { Fixed-effects } \\
\text { model }\end{array}$ & $5.21(2.19-12.4 \mid)$ & 0.00 & 0.00 & 0.62 & 1.00 & 0.58 \\
\hline $\begin{array}{l}\text { PI6 methylation } \\
\text { (neoplasm vs adjacent) }\end{array}$ & 4 & $\begin{array}{l}\text { Random-effects } \\
\text { model }\end{array}$ & 7.18 (2.3I-22.33) & 0.00 & 74.2 & 0.01 & 0.09 & 0.30 \\
\hline $\begin{array}{l}\text { PI6 methylation } \\
\text { (neoplasm vs normal) }\end{array}$ & 2 & $\begin{array}{l}\text { Fixed-effects } \\
\text { model }\end{array}$ & $24.89(3.38-183.03)$ & 0.00 & 40.0 & 0.20 & 1.00 & - \\
\hline $\begin{array}{l}\text { PI6 methylation } \\
\text { (neoplasm vs cirrhosis) }\end{array}$ & 5 & $\begin{array}{l}\text { Random-effects } \\
\text { model }\end{array}$ & $5.92(1.78-19.68)$ & 0.00 & 60.1 & 0.04 & 1.00 & 0.58 \\
\hline $\begin{array}{l}\text { PI6 methylation } \\
\text { (neoplasm vs } \mathrm{CHB} \text { ) }\end{array}$ & 3 & $\begin{array}{l}\text { Random-effects } \\
\text { model }\end{array}$ & $12.12(0.75-196.50)$ & 0.08 & 90.0 & 0.00 & 1.00 & 0.47 \\
\hline
\end{tabular}

Abbreviations: $\mathrm{HBV}$, hepatitis $\mathrm{B}$ virus; $\mathrm{HCC}$, hepatocellular carcinoma; $\mathrm{CHB}$, chronic hepatitis $\mathrm{B}$. 
A

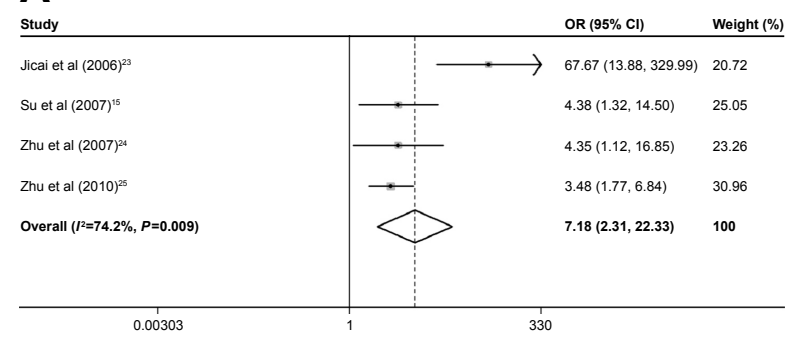

C

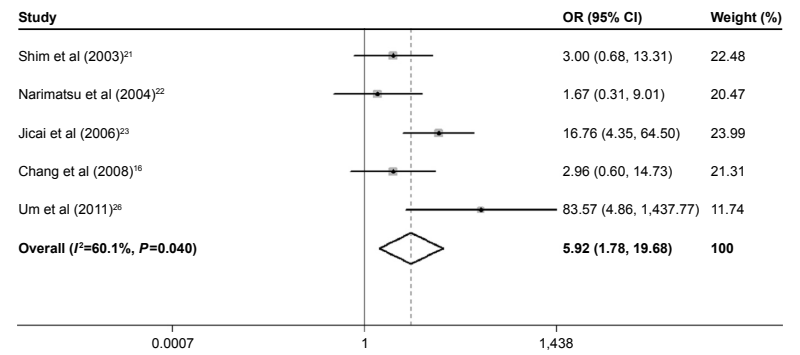

B

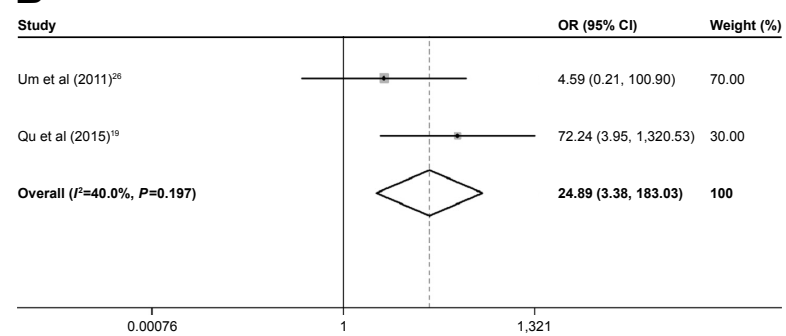

D

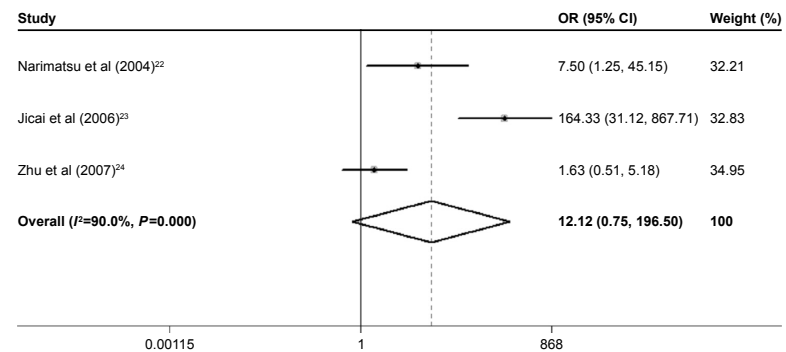

Figure 3 Forest plots of PI6 promoter region methylation and the risk of HBV-related HCC.

Notes: (A) Neoplasm vs adjacent tissues; (B) neoplasm vs normal tissues; (C) neoplasm vs cirrhosis tissues; (D) neoplasm vs CHB tissues. Each square represents an OR for each specific study, with square sizes proportional to the weight. Weights are from random-effects analysis.

Abbreviations: $\mathrm{CHB}$, chronic hepatitis $\mathrm{B} ; \mathrm{HBV}$, hepatitis $\mathrm{B}$ virus; $\mathrm{HCC}$, hepatocellular carcinoma.

showed no publication bias in HBV-related HCC tumor tissues vs adjacent tissues, normal tissues, cirrhosis tissues, and CHB tissues (Table 2 and Figure 5).

\section{Discussion}

To the best of our knowledge, HBV infection is one of the most associated factors in hepatocarcinogenesis. HBV has been proved to integrate into the host genome and interfere with cell proliferation and invasion, DNA repair, as well as epigenetic modification. ${ }^{27}$ In areas with high prevalence of HBV infection, a spectrum of liver disease has been formed, extending from $\mathrm{CHB}$ to cirrhosis, even to HCC. ${ }^{28,29}$ Therefore, it is of great importance to explore the molecular mechanisms underlying HBV-related HCC.

Previous studies demonstrated that HBV infection could lead to hypermethylation, and aberrant DNA methylation has been proved to be an early event in hepatocarcinogenesis. ${ }^{30-32}$ Consequently, the analysis of DNA methylation could be

\section{A}
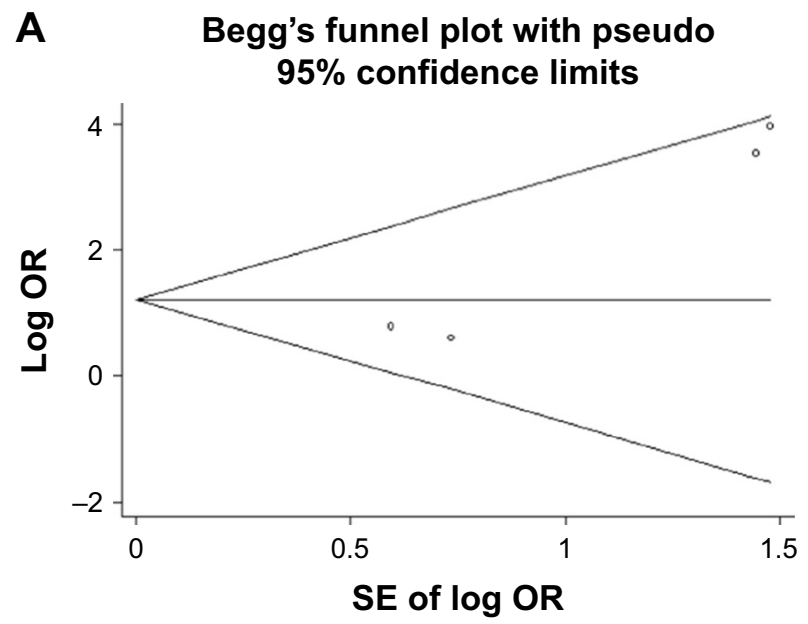

B Begg's funnel plot with pseudo $95 \%$ confidence limits

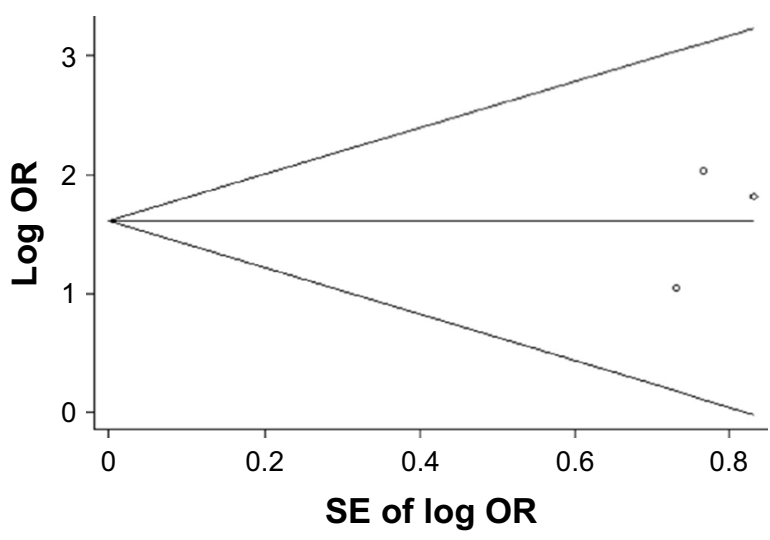

Figure 4 Begg's funnel plot analysis for publication bias between GSTPI methylation and HBV-related HCC susceptibility. Notes: (A) Neoplasm vs normal tissues; (B) neoplasm vs cirrhosis tissues.

Abbreviations: GSTPI, glutathione-S-transferase Pi I; HBV, hepatitis B virus; HCC, hepatocellular carcinoma. 
A

\section{Begg's funnel plot with pseudo $95 \%$ confidence limits}

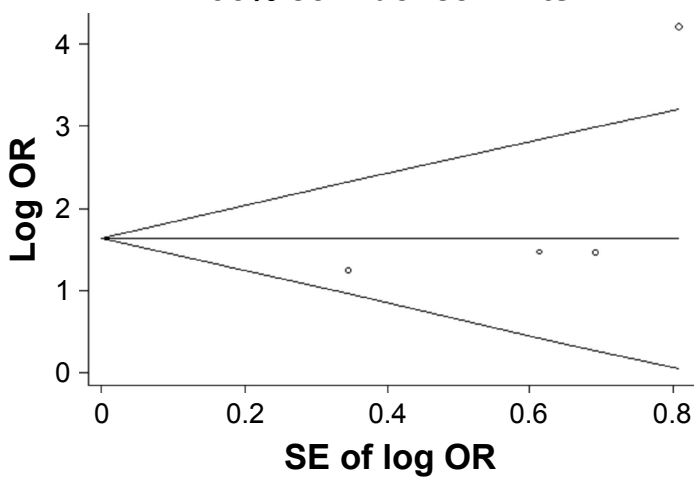

C Begg's funnel plot with pseudo $95 \%$ confidence limits

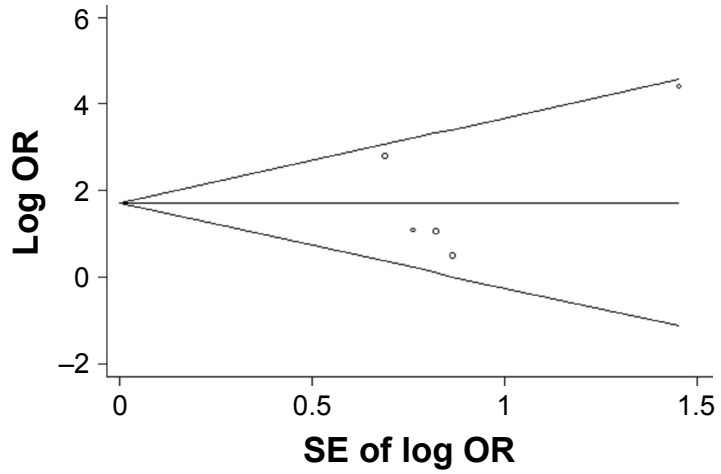

\section{B Begg's funnel plot with pseudo $95 \%$ confidence limits}

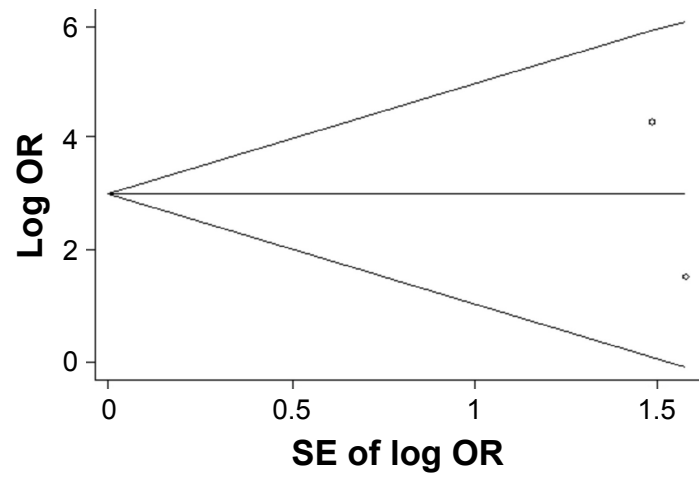

D Begg's funnel plot with pseudo $95 \%$ confidence limits

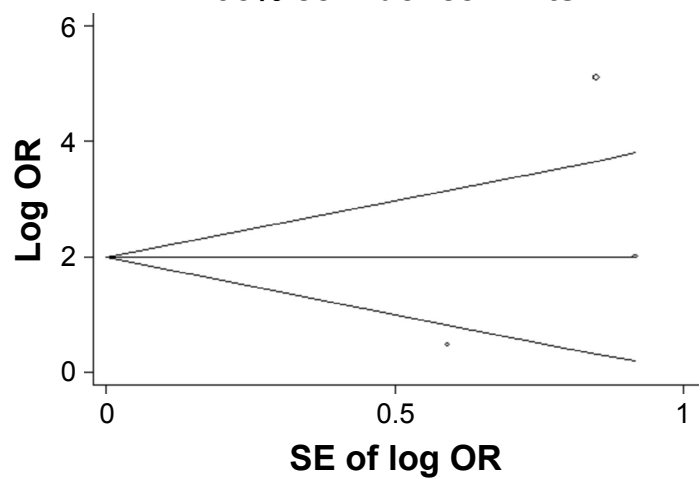

Figure 5 Begg's funnel plot analysis for publication bias between PI6 methylation and HBV-related HCC susceptibility.

Notes: (A) Neoplasm vs adjacent tissues; (B) neoplasm vs normal tissues; (C) neoplasm vs cirrhosis tissues; (D) neoplasm vs CHB tissues.

Abbreviations: $\mathrm{CHB}$, chronic hepatitis $\mathrm{B}$; HBV, hepatitis B virus; $\mathrm{HCC}$, hepatocellular carcinoma.

an effective method for assessing reliable and powerful biomarkers for HBV-related HCC, which will greatly improve the diagnosis and treatment of it.

The GSTP1 is a gene encoding an enzyme with detoxifiation and protein-binding functions. In addition to the overexpression of GSTP1 observed in many neoplasms, GSTP1 genetic polymorphisms and abnormal $\mathrm{CpG}$ island methylation have also been thought to function in susceptibility to several cancers, including breast, lung, and liver cancers. ${ }^{33-36}$ According to the previous studies, GSTP1 promoter methylation may be involved in the occurrence and development of HBV-related HCC. ${ }^{15,16,18,19}$ However, there are contradictory results concerning the role of GSTP1 promoter methylation in the progression of HBV-related HCC as well. ${ }^{17,20} \mathrm{In}$ view of the conflicting evidence on this issue, we performed this meta-analysis to evaluate the exact relationship between GSTP1 promoter methylation and increased risk of HBVrelated HCC. Consequently, our results confirmed that the methylation rates of GSTP1 gene in cancer tissues were considerably higher than those of normal controls $(\mathrm{OR}=6.05$,
$95 \% \mathrm{CI}=1.20-30.52)$ as well as cirrhosis tissues $(\mathrm{OR}=5.21$, $95 \% \mathrm{CI}=2.19-12.41$ ), suggesting the importance of GSTP1 promoter region methylation in the development of HBVrelated HCC.

In addition, P16 is another important TSG for the suppression of tumor growth. ${ }^{37,38} \mathrm{P} 16$ gene promoter region methylation represents the most common mechanism of P16 inactivation in HBV-induced human HCC. ${ }^{39}$ As several studies demonstrated, the methylation of P16 may participate in the development of HBV-related HCC..$^{18,19,21,22}$ However, the negative results indicated that the exact relationship of $\mathrm{P} 16$ gene promoter region methylation with HBV-related HCC susceptibility was still inconclusive. ${ }^{17,20}$ In the present study, an apparently increased risk of HBVrelated HCC was found in tumor tissue in comparison with paracancerous tissue $(\mathrm{OR}=7.18,95 \% \mathrm{CI}=2.31-22.33)$, normal liver tissue $(\mathrm{OR}=24.89,95 \% \mathrm{CI}=3.38-183.03)$, and cirrhosis ( $\mathrm{OR}=5.92,95 \% \mathrm{CI}=1.78-19.68)$, conforming that $\mathrm{P} 16$ promoter methylation is a risk factor for HBV-related HCC. 
In this meta-analysis, the publication bias was examined in the eligible studies using Begg's test and Egger's test, and the funnel plots showed that the data did not have a considerable discrepancy among studies. Furthermore, we conducted sensitivity analysis and consistent results were found, which revealed that no single study could affect the overall conclusion.

However, several potential limitations must be emphasized in this study. First, the limited studies with small sample size may limit the power of statistics. Second, moderate heterogeneity across included studies existed in separate comparisons, which may have an influence on the interpretation of our results. Third, as the pathogenesis of HBV-related HCC has a significant difference in diverse countries and regions, $\mathrm{HBV}$ genotypes $\mathrm{B}$ and $\mathrm{C}$ are common in Asia while genotypes $\mathrm{A}$ and $\mathrm{D}$ are prevalent in Europe, but the ethnicity of the population in this meta-analysis was mainly Asian. Therefore, the results of this meta-analysis were mainly adapted to Asian population, and large-scale subjects with multi-ethnic populations are needed.

\section{Conclusion}

This meta-analysis showed that GSTP1 and P16 promoter methylation might play an important role in HBV-related HCC initiation and progression, and GSTP1 and P16 methylation in promoter region could obviously increase the risk of HBV-related HCC in patients with cirrhosis, which might be promising biomarkers for the early clinical diagnosis of HBV-related HCC. However, in consideration of the limitations mentioned earlier, more large-scale and well-designed studies will provide more insights into the role of GSTP1 and $\mathrm{P} 16$ promoter methylation in the risk and pathogenesis of HBV-related HCC.

\section{Acknowledgment}

This project was supported by the Sichuan Science and Technology Department Project (14JC0086).

\section{Disclosure}

The authors report no conflicts of interest in this work.

\section{References}

1. Li W, Li L, Han J, Wu H. Liver transplantation vs liver resection in patients with HBV-related hepatocellular carcinoma beyond Milan criterion: A meta-analysis. Clin Transplant. 2018;32(3):e13193.

2. El-Serag HB. Epidemiology of viral hepatitis and hepatocellular carcinoma. Gastroenterology. 2012;142(6):1264-1273.

3. Mani SKK, Andrisani O. Hepatitis B virus-associated hepatocellular carcinoma and hepatic cancer stem cells. Genes. 2018;9(3):E137.

4. Ganem D, Prince AM. Hepatitis B virus infection - natural history and clinical consequences. $N$ Engl J Med. 2004;350(11):1118-1129.
5. Tian Y, Yang W, Song J, Wu Y, Ni B. Hepatitis B virus X protein-induced aberrant epigenetic modifications contributing to human hepatocellular carcinoma pathogenesis. Mol Cell Biol. 2013;33(15):2810-2816.

6. Dexheimer GM, Alves J, Reckziegel L, Lazzaretti G, Abujamra AL. DNA methylation events as markers for diagnosis and management of acute myeloid leukemia and myelodysplastic syndrome. Dis Markers. 2017;2017:5472893-14.

7. Lorincz MC, Schübeler D. Evidence for converging DNA methylation pathways in placenta and cancer. Dev Cell. 2017;43(3):257-258.

8. Weisenberger DJ, Liang G, Lenz HJ. DNA methylation aberrancies delineate clinically distinct subsets of colorectal cancer and provide novel targets for epigenetic therapies. Oncogene. 2018;37(5):566-577.

9. Hardy T, Mann DA. Epigenetics in liver disease: from biology to therapeutics. Gut. 2016;65(11):1895-1905.

10. Nishida N, Kudo M. Epigenetic regulation and development of hepatocellular carcinoma. Nihon Shokakibyo Gakkai Zasshi. 2016;113(5): $775-784$.

11. Zhang C, Li J, Huang T, et al. Meta-analysis of DNA methylation biomarkers in hepatocellular carcinoma. Oncotarget. 2016;7(49): 81255-81267.

12. Jain $\mathrm{S}$, Chen $\mathrm{S}$, Chang $\mathrm{KC}$, et al. Impact of the location of $\mathrm{CpG}$ methylation within the GSTP1 gene on its specificity as a DNA marker for hepatocellular carcinoma. PLoS One. 2012;7(4):e35789.

13. Piepkorn M. Melanoma genetics: an update with focus on the CDKN2A(p16)/ARF tumor suppressors. J Am Acad Dermatol. 2000; 42(5 Pt 1):705-726.

14. Lukas J, Parry D, Aagaard L, et al. Retinoblastoma-protein-dependent cell-cycle inhibition by the tumour suppressor p16. Nature. 1995; 375(6531):503-506.

15. Su PF, Lee TC, Lin PJ, et al. Differential DNA methylation associated with hepatitis B virus infection in hepatocellular carcinoma. Int J Cancer. 2007;121(6):1257-1264.

16. Chang H, Yi B, Li L, et al. Methylation of tumor associated genes in tissue and plasma samples from liver disease patients. Exp Mol Pathol. 2008;85(2):96-100.

17. Feng Q, Stern JE, Hawes SE, Lu H, Jiang M, Kiviat NB. DNA methylation changes in normal liver tissues and hepatocellular carcinoma with different viral infection. Exp Mol Pathol. 2010;88(2):287-292.

18. Lambert MP, Paliwal A, Vaissière T, et al. Aberrant DNA methylation distinguishes hepatocellular carcinoma associated with $\mathrm{HBV}$ and $\mathrm{HCV}$ infection and alcohol intake. J Hepatol. 2011;54(4):705-715.

19. Qu Z, Jiang Y, Li H, Yu DC, Ding YT. Detecting abnormal methylation of tumor suppressor genes GSTP1, P16, RIZ1, and RASSF1A in hepatocellular carcinoma and its clinical significance. Oncol Lett. 2015; 10(4):2553-2558.

20. Dong X, Hou Q, Chen Y, Wang X. Diagnostic value of the methylation of multiple gene promoters in serum in hepatitis B virus-related hepatocellular carcinoma. Dis Markers. 2017;2017:2929381-6.

21. Shim YH, Yoon GS, Choi HJ, Chung YH, Yu E. p16 Hypermethylation in the early stage of hepatitis B virus-associated hepatocarcinogenesis. Cancer Lett. 2003;190(2):213-219.

22. Narimatsu T, Tamori A, Koh N, et al. p16 promoter hypermethylation in human hepatocellular carcinoma with or without hepatitis virus infection. Intervirology. 2004;47(1):26-31.

23. Zhang JC, Yu ZT, Lu J, et al. Persistent infection of hepatitis B virus is involved in high rate of p16 methylation in hepatocellular carcinoma. Mol Carcinog. 2006;45(7):530-536.

24. Zhu R, Li BZ, Li H, et al. Association of p16INK4A hypermethylation with hepatitis B virus X protein expression in the early stage of HBVassociated hepatocarcinogenesis. Pathol Int. 2007;57(6):328-336.

25. Zhu YZ, Zhu R, Fan J, et al. Hepatitis B virus X protein induces hypermethylation of p16(INK4A) promoter via DNA methyltransferases in the early stage of HBV-associated hepatocarcinogenesis. J Viral Hepat. 2010;17(2):98-107.

26. Um TH, Kim H, Oh BK, et al. Aberrant $\mathrm{CpG}$ island hypermethylation in dysplastic nodules and early $\mathrm{HCC}$ of hepatitis B virus-related human multistep hepatocarcinogenesis. J Hepatol. 2011;54(5):939-947. 
27. Geng M, Xin X, Bi LQ, Zhou LT, Liu XH. Molecular mechanism of hepatitis B virus $\mathrm{X}$ protein function in hepatocarcinogenesis. World $J$ Gastroenterol. 2015;21(38):10732-10738.

28. Fung SK, Lok AS. Management of patients with hepatitis B virusinduced cirrhosis. J Hepatol. 2005;42 Suppl(1):S54-S64.

29. Tanaka M, Katayama F, Kato H, et al. Hepatitis B and C virus infection and hepatocellular carcinoma in China: a review of epidemiology and control measures. J Epidemiol. 2011;21(6):401-416.

30. Herman JG, Baylin SB. Gene silencing in cancer in association with promoter hypermethylation. N Engl J Med. 2003;349(21):2042-2054.

31. Egger G, Liang G, Aparicio A, Jones PA. Epigenetics in human disease and prospects for epigenetic therapy. Nature. 2004;429(6990): $457-463$.

32. Kew MC. Hepatitis B virus $x$ protein in the pathogenesis of hepatitis B virus-induced hepatocellular carcinoma. J Gastroenterol Hepatol. 2011;26(Suppl 1):144-152.

33. Nakazato H, Suzuki K, Matsui H, et al. Association of genetic polymorphisms of glutathione-S-transferase genes (GSTM1, GSTT1 and GSTP1) with familial prostate cancer risk in a Japanese population. Anticancer Res. 2003;23(3C):2897-2902.
34. Chen G, Zhang H, Sun L, et al. Prognostic significance of GSTP1 in patients with triple negative breast cancer. Oncotarget. 2017;8(40): 68675-68680.

35. Wang Y, Ren BU, Zhang L, Guo Z. Correlation between metabolic enzyme GSTP1 polymorphisms and susceptibility to lung cancer. Exp Ther Med. 2015;10(4):1521-1527.

36. Hann HW, Jain S, Park G, Steffen JD, Song W, Su YH. Detection of urine DNA markers for monitoring recurrent hepatocellular carcinoma. Hepatoma Res. 2017;3:105-111.

37. Mohd Ridah LJ, A Talib N, Muhammad N, Hussain FA, Zainuddin N. p16 Tumor suppressor gene methylation in diffuse large B cell lymphoma: a study of 88 cases at two hospitals in the east coast of Malaysia. Asian Pac J Cancer Prev. 2017;18(10):2781-2785.

38. Sun G, Zhang C, Feng M, et al. Methylation analysis of p16, SLIT2, SCARA5, and Runx3 genes in hepatocellular carcinoma. Medicine. 2017;96(41):e8279.

39. Lv X, Ye G, Zhang X, Huang T. p16 Methylation was associated with the development, age, hepatic viruses infection of hepatocellular carcinoma, and p16 expression had a poor survival: a systematic meta-analysis (PRISMA). Medicine. 2017;96(38):e8106.
OncoTargets and Therapy

\section{Publish your work in this journal}

OncoTargets and Therapy is an international, peer-reviewed, open access journal focusing on the pathological basis of all cancers, potential targets for therapy and treatment protocols employed to improve the management of cancer patients. The journal also focuses on the impact of management programs and new therapeutic agents and protocols on

\section{Dovepress}

patient perspectives such as quality of life, adherence and satisfaction. The manuscript management system is completely online and includes a very quick and fair peer-review system, which is all easy to use. Visit http://www.dovepress.com/testimonials.php to read real quotes from published authors. 